\title{
Structure of an Indian Summer Monsoon System with around 40-Day Period
}

\author{
by Tetsuzo Yasunari
}

The Center for Southeast Asian Studies, Kyoto University, Kyoto 606, Japan (Manuscript received 9 September 1980, in revised form 1 February 1981)

\begin{abstract}
Through the analysis of the geopotential and wind fluctuation during the summer monsoon season over and around India, the predominant periodicity of about 40 days was confirmed especially in the lower and upper troposphere as a major active-break cycle of the monsoon activity. As well as the cloudiness fluctuation of the same period (Yasunari, 1979; Yasunari, 1980), these elements except the geopotential height in the upper level showed a marked northward propagation from the equator toward the Himalayan region. The geopotential height at $200 \mathrm{mb}$ showed, in contrast, a standing oscillation over India. Cross-spectral analyses revealed that the vertical structure of the atmosphere is gradually modified during the northward phase shift of the anomaly cloudiness with the 40-day period. This modification is most apparent in the temperature field. The modification of the vertical structure from the south to the north over India seems to be attributed to the gradual enhancement of cumulus convection from the south to the north. It is also suggested that this cycle is caused by the periodical cold air outbreak over the middle and upper troposphere of the equatorial zone which may be associated with the index cycle of the westerly wave movements in the Southern Hemisphere. Finally, a multicell structure of the anomaly Hadley circulation regime over India through the Indian Ocean was proposed, which gives reasonable interpretations on various aspects of the active-break cycle of monsoon activity with this mode.
\end{abstract}

\section{Introduction}

Through the analyses of cloudiness fluctuations by the present author (Yasunari, 1979; Yasunari, 1980 ), a predominant periodicity of 30 to 40 days was confirmed as a quasi-stationary mode over and around India during the summer monsoon period: The fluctuation of this periodicity shows a marked northward phase propagation from the equatorial zone to the mid latitudes (around $30^{\circ} \mathrm{E}$ ) over Asian monsoon area, most apparently over India-Indian Ocean sector.* The fluctuation of this mode seems to be correspondent with the major active-break cycle of monsoon activity. It also seems that the cloudiness fluctuation of this period appears as a periodical northward shift of ITCZ cloud band at the longitudinal sector over India through Southeast Asia.

\footnotetext{
* Recently, Sikka and Gadgil (1979) found very similar features by using the satellite cloudiness data from 1973 to 1977.
}

It was also pointed out in the former paper (Yasunari, 1979) that the fluctuation in the meridional plane is closely related to the eastward moving equatorial disturbance studied by Madden and Julian (1971, 1972). Recently, Chang and Wang (1976) found that the surface pressure field over ITCZ of the western Pacific also shows the dominant oscillation of the same period range (5 to 7 weeks).

The synoptic feature of each stage of the major active-break cycle was formerly suggested by Rahmatullarh (1952), though he did not comment on the time scale of the cycle. However, the horizontal and vertical structure of the monsoon circulation regime associated with this mode has not yet been clarified.

Many studies have already described the difference between the "active and the "break" phase in the atmospheric field over India (e.g., Alexander et al., 1978; Hamilton, 1977, etc.). However, as pointed out already (e.g., Krishnamurti 
and Bhalme, 1976; M. Murakami, 1976), there exists another dominant periodicity of about 15 days as an active-break cycle, and the spatial structure of this period range shows a somewhat different feature from the 30-40 day period mode (Yasunari, 1979). As most of the previous studies did not separate these two modes each other, the time scales and related space structure of "break" (or "active") phases were sometimes confusing. As for the quasi-biweekly mode, a few studies (M. Murakami, 1976; Yasunari, 1979) revealed the spatial structure of the lower level over and around India, though the complete three-dimensional structure has not yet been analyzed.

In this paper, we focus to clarify the horizontal and vertical structure of the fluctuation of about 40-day period, especially in the latitude-height section over India. Some considerations on the equatorial and the Southern Hemispheric circulations will also be made, which are supposed to be the most important exciting force of this mode over India. Finally, we will present one model of the meridional (or local Hadley) circulations along the line from India to the Southern Hemisphere associated with the active-break cycle of this period range. A brief description will be made on the structure of the quasi-biweekly mode, only for a comparison with the mode of 30 to 40-day period.

\section{Data}

Daily upper air data over India (from "Aerological Data of India", India Meteorological Department) is a main data source for the present analysis. The surface weather maps (from "Indian daily weather report") were used to examine

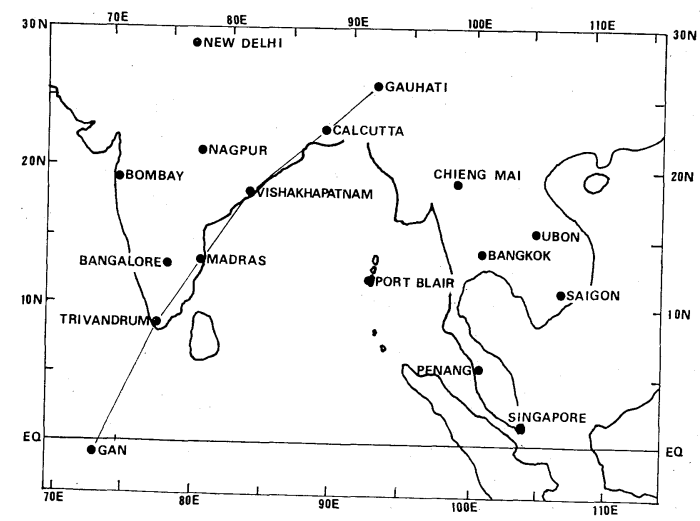

Fig. 1 Observation stations over and around India used in this study. Cross section for Fig. 5, 7, 9 and 14 is indicated with the line from Gauhati and Gan. the surface synoptic conditions. To cover the area over Indian Ocean and Southeast Asia, the upper air data over Thailand, Vietnam, Malaysia, Singapore and at Gan Island were additionally used. The Southern Hemisphere $500 \mathrm{mb}$ charts (published by the Australian Bureau of Meteorology) were used for the analysis of the Southern Hemisphere. The period for the analysis is chosen from June to September 1969, when the mean monsoon activity is considered to be nearly normal. The stations over and around India used in this study are shown in Fig. 1.

\section{Fluctuation of the 40-day period in the geo- potential field}

\section{a) Spectral ianalysis of the geopotential field}

The fluctuations in the geopotential (or pressure) field may be important indices of monsoon activity, since it is well known that the monsoon trough in the lower troposphere and the Tibetan High in the upper troposphere change their intensity and position associated with the activebreak cycle.

To examine the dominant periodicities, power spectral analysis of MEM method (e.g., Ulrich ind Bishop, 1975, etc.) is applied to the time series of geopotential field during the monsoon period (122 days from June 1 to September 30). The advantage of this method was commented already in the previous paper (Yasunari, 1979). Maximum lag number of 25 days is adopted,

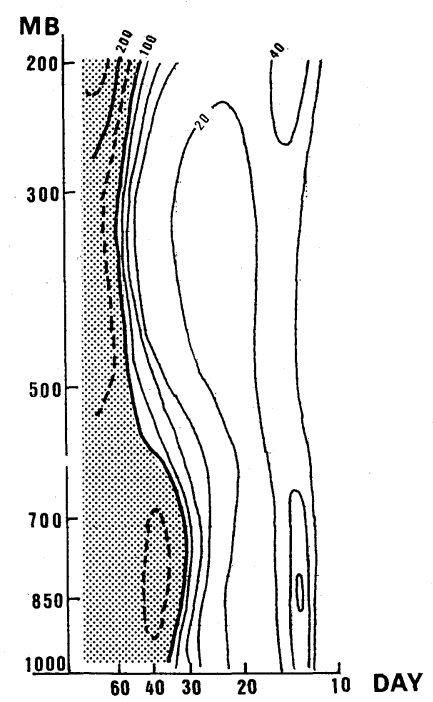

Fig. 2 Vertical distribution of the power spectra of the geopotential height at Nagpur. Units are $\mathrm{m}^{2} \bullet$ day and the values more than 100 are shaded. 
while the total record length is 122 days. The results of spectral analysis on the geopotential field at Nagpur are shown in Fig. 2. A remarkable spectral peak of around 40-day period exists at the lower level $(700$ to $850 \mathrm{mb})$, which seems to be closely related to the oscillation of monsoon trough over northern India. The spectral peak of around 15 days is also prominent throughout the troposphere.

\section{b) Horizontal structure of the geopotential height fluctuation}

As already noted in the previous papers (Yasunari, 1979; Yasunari, 1980), cloudiness fluctuation of 30 to 40-day period shows a northward phase shift most apparently over the longitudinal sector of India-Indian Ocean area. Fig. 3 shows the latitude time section of the filtered cloudiness for 1969 along the longitudinal sector of $70^{\circ} \mathrm{E}$ $90^{\circ} \mathrm{E}$ (refer to Yasunari, 1980). Precisely speaking, the phase gradually tends to become parallel to the direction of the mean monsoon trough or the great Himalayan range over northern India, as shown in Fig. 12(a) of Yasunari (1979). Based on this result, we examined the cross sections of filtered pressure field along the line nearly normal to the monsoon trough as shown in Fig. 1. To separate the fluctuations of about 40-day period and the quasi-biweekly period, two time filters are adopted. The frequency responses are indicated in Fig. 4. The time cross-sections of the filtered geopotential height at $850 \mathrm{mb}$ are shown in Fig. 5(b) and 5(c). Five-day moving smoothed height is also illustrated in Fig. 5(a). Fig. 5(a) shows the quasi-stationary existence of monsoon trough over northern India, fluctuating quasiperiodically with a 10 to 20 -day period but with a large "break" phase at some time. The intensities of its maximum (or minimum) phases are also quite different from one to the other. It is noteworthy that the mixed feature with a quasiperiodical and a random fluctuation in Fig. 5(a) can clearly be explained as the composite fluctuation of a northward movement of 40-day period (Fig. 5(b) ) and a quasi-standing oscillation of about 15-day period (Fig. 5(c)). The oscillation of about 15-day period in Fig. 5(c) appears actually as a northwestward propagation of wave from the Bay of Bengal toward northwestern India nearly normal to the section line in Fig. 1. The difference of propagation between the two periodicities mentioned above was confirmed in the spatial distribution of phase lag obtained by the cross-spectral analysis (Fig. 6). In Fig. 6, the reference point is chosen at Nagpur in central India.

Krishnamurti and Ardanuy (1980) noted that the surface pressure fluctuation of the 30 to 40-day period is correspondent with the eastward propagation of zonal wave number 1 and 2 at the monsoon trough latitudes. The phase-lag distribution of the 40-day period in Fig. 6 may be compatible with their observation.

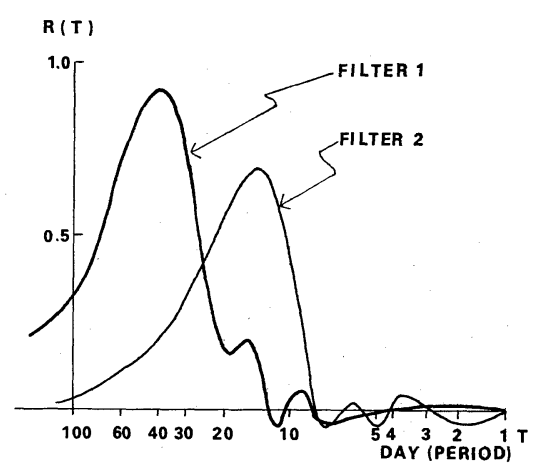

Fig. 4 Frequency response of the two filters. The peak of filter 1 exists at 40-day period and that of filter 2 is at about 14-day period.

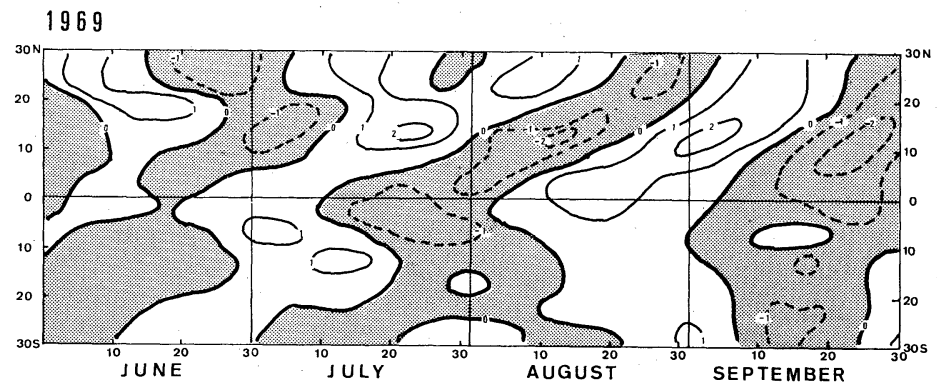

Fig. 3 Time latitude section of filtered cloudiness for the 40-day period along the longitudinal sector of $70^{\circ}-90^{\circ} \mathrm{E}$. Unit of contour line is 1.0 and negative values are shaded. 
(a)

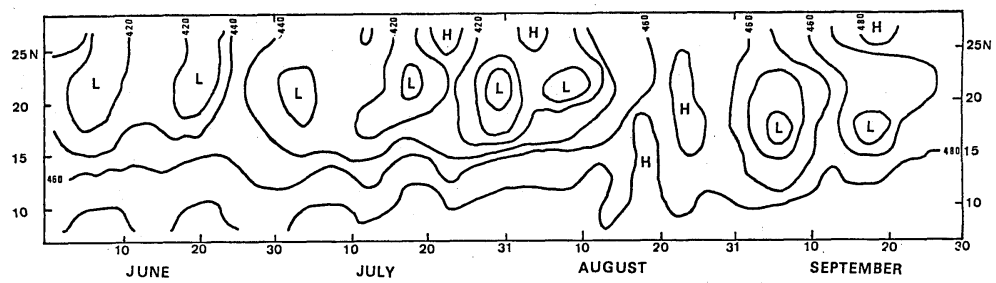

(b)

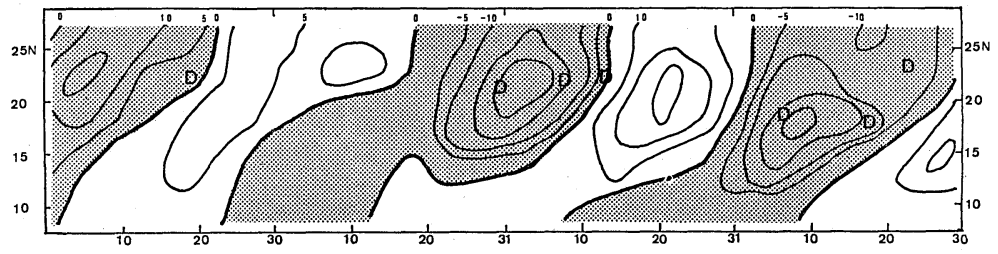

(c)

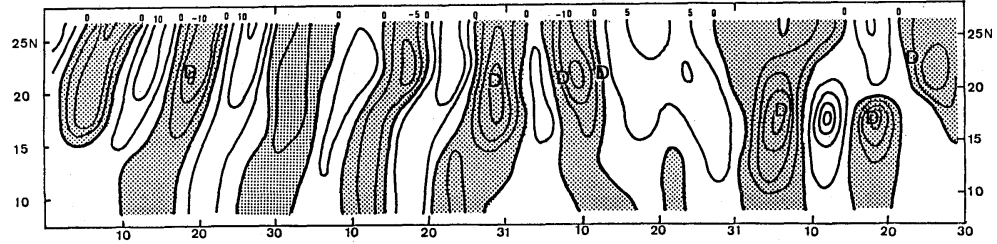

Fig. 5 Cross sections of the geopotential height at $850 \mathrm{mb}$ along the line shown in Fig. 1, by using (a) 5-day moving averaged data (b) data by filter 1, and (c) data by filter 2 . Contour intervals are (a) $20 \mathrm{~m}$, (b), (c) $5 \mathrm{~m}$. The areas of negative values are shaded in (b) and (c).

It was remarkably noticed that all the monsoon depressions* of this year (as indicated with "D" in Fig. 5(b) and 5(c) appeared uniquely in the phases of negative pressure anomaly of the 40-day period as well as the biweekly period. Additionally, the two intense depressions, whose pressures around the center area indicate more than $8 \mathrm{mb}$ below the normal, occurred just at the minimum phases (e.g., July 30-31 and September 7) of the 40-day period.

In contrast with the feature of $850 \mathrm{mb}$ level, the filtered geopotential height of $200 \mathrm{mb}$ level along the Gauhati-Gan line (refer to Fig. 1) changes its sign nearly-simultaneously from $30^{\circ} \mathrm{N}$ to the equatorial zone, as shown in Fig. 7. Precisely speaking, the center area of the maximum variance exists at $15^{\circ}-20^{\circ} \mathrm{N}$ zone and the variance is relatively small to the north and south of it or it has the opposite sign to the center area. That is, the geopotential height in the upper level shows a standing osciliation with the maximum variance over central India. If we compare Fig. 7 with Fig. 5(b), it is evident that the maximum (or minimum) height over central India is cou-

* Following the definition by Rao (1976), the low pressure system is referred to as "monsoon depression" when surface winds exceed $17 \mathrm{kt}$ over the sea.

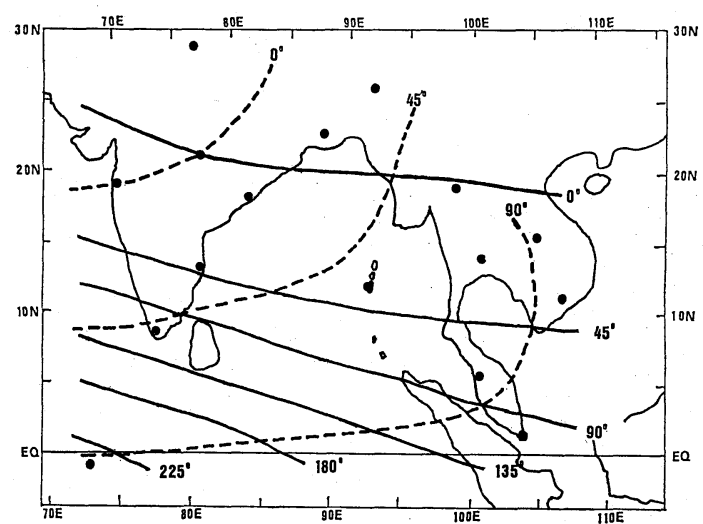

Fig. 6 Phase lag relations of the geopotential height at $850 \mathrm{mb}$ for the 40 -day period (solid lines) and the 13.3-day period (dashed lines). The reference point is located at Nagpur.

pled with the trough (or ridge) at $850 \mathrm{mb}$. However, when we made the anomaly data from the daily mean height along the section line (refer to Fig. 1) and then composed time section with the same manner as Fig. 7, we would notice though weakly the tendency of the northward phase shift of the anomaly height (not shown). This implies that during the course of the north- 


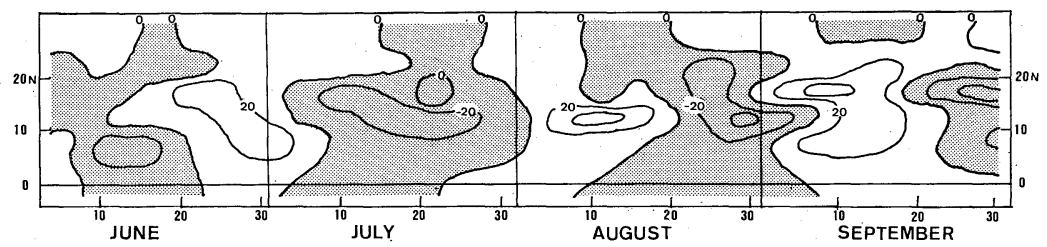

Fig. 7 Cross section of the filtered geopotential height at $200 \mathrm{mb}$ along the line shown in

Fig. 1. Contour interval is $20 \mathrm{~m}$. Negative areas are shaded.

ward shift of the transient anomaly the areal mean field changes with far larger amplitude than the transient anomaly. In other words, there may exist the interaction between the transient field and the (areal) mean field with the maximum rate over central India.

\section{Fluctuations of the 40-day period in the wind field}

\section{a) Spectral analysis of the wind field}

The mean monsoon circulation is characterized principally as a meridional (or Hadley type) circulation containing the southwest monsoon flow and the easterly jet in the lower and upper troposphere respectively. Consequently, the wind field should be an important indicator of the fluctuation of the monsoon circulation.

The MEM spectral analysis was applied to the wind field at some stations, to check the dominant periodicities in the wind fluctuation. We selected the data of Trivandrum, Nagpur and Calcutta, as a representative point of southern India, central India and the monsoon trough region of northern India, respectively. The results of the zonal and meridional wind component at the three stations are shown in Fig. 8 in terms of the vertical distribution of power spectral densities. At Trivandrum the strong concentration of power at 40 -day period is prominent at around $200 \mathrm{mb}$ and $700 \mathrm{mb}$ levels in the zonal wind component. The secondary maximum is seen at the wide period range from 10 to 20 days both in the upper and lower troposphere. The similar feature on the 40-day period exists in the meridional wind component. In the mean state of the summer monsoon period, Trivandrum is located nearly under the center core of the easterly jet in the upper troposphere. Henceforth, the total spectral feature of wind field over this station shows that both southwest monsoon flow in the lower troposphere and the easterly jet in the upper troposphere fluctuate predominantly with the 40-day period. At Nagpur the total feature is similar to that of Trivandrum, though the power spectral densities are distributed with a wide period range (longer than 40 days) in the low frequency band. This may be due to a relatively large variance of the seasonal march component over this area. At Calcutta the concentration of power is seen only in the lower troposphere (700$850 \mathrm{mb}$ level), which may be attributed to the relatively small variance of the upper wind over there. The spectral peak in the quasi-biweekly period is also prominent mainly in the lower half of the troposphere.

At Nagpur and Calcutta, the power densities of the quasi-biweekly mode are relatively large in the zonal component, which may suggest that this mode is related to the frequency of some weather phenomena dominating over and around the monsoon trough region such as the monsoon depressions.

\section{b) Horizontal structure of the wind fluctuation}

Next, we examined the horizontal structure of the 40-day period of the zonal wind component along the same cross-section as Fig. 5, at the lower troposphere $(850 \mathrm{mb})$ and upper troposphere $(200 \mathrm{mb})$. The result of $850 \mathrm{mb}$ is shown in Fig. 9(a). Very similarly to Fig. 5 of the geopotential field, the phase of the fluctuation of the zonal wind shows a distinct northward movement. It is apparent in Fig. 5(b) and Fig. 9(a) that the maximum westerly (or easterly) and the minimum (or maximum) geopotential height are roughly in phase over the $10^{\circ}-20^{\circ} \mathrm{N}$ latitude zone.

The cross-section of the filtered zonal wind at $200 \mathrm{mb}$ is also shown in Fig. 9(b). Very similar to the feature of the lower level, a northward movement of the filtered wind could be depicted most distinctly to the south of about $15^{\circ} \mathrm{N}$. The disappearance of the northward propagation to the north of it may be closely connected with the dominancy of the standing oscillation of the geopotential height over central India as shown in Fig. 7.

It should be noted that the phase relationship between the lower and the upper levels changes 
(a)
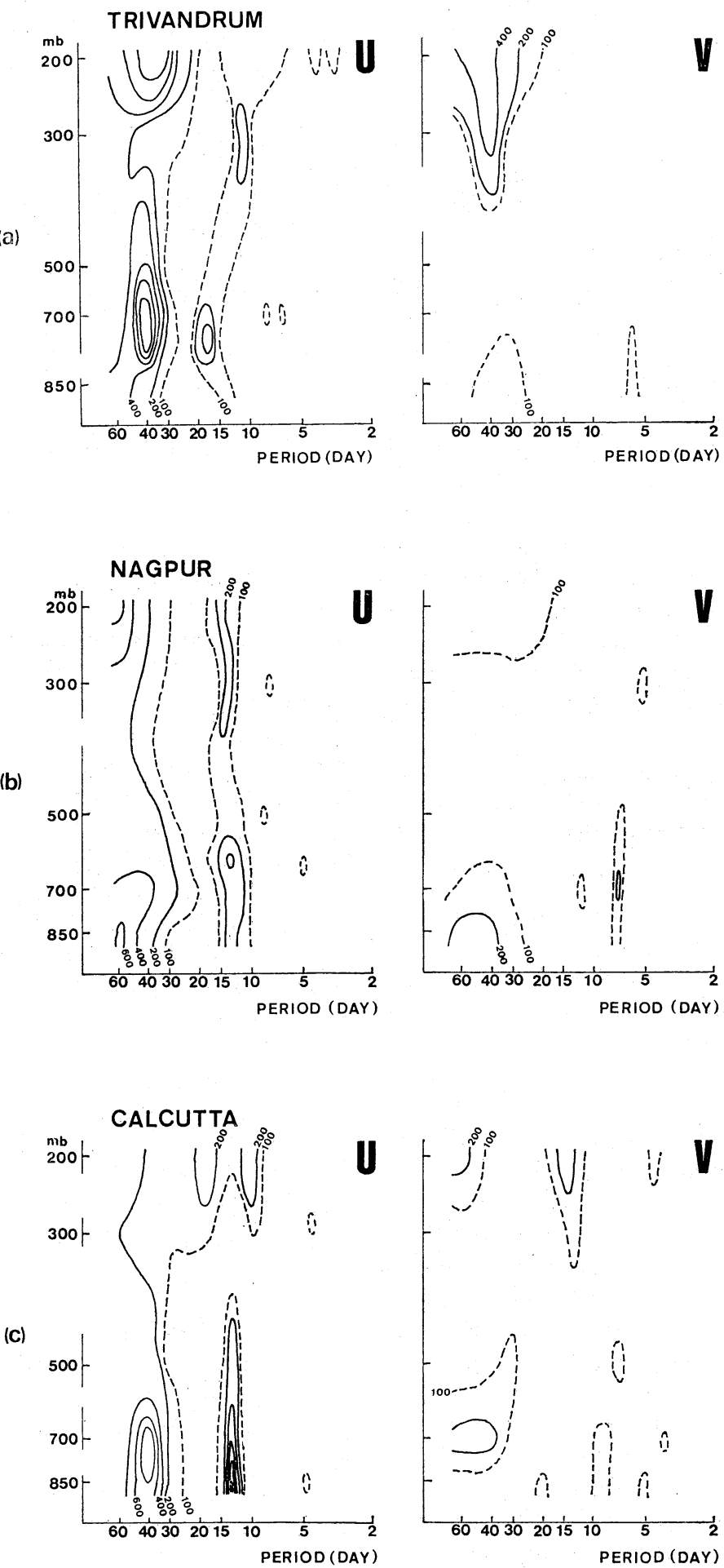

Fig. 8 Vertical distributions of the power spectra of the zonal (left) and the meridional (right) wind components for (a) Trivandrum (b) Nagpur and (c) Calcutta. Units are $(\mathrm{m} / \mathrm{sec})^{2} \bullet$ day and contour intervals are 200 (solid line) and 100 (dashed line). 
(a)

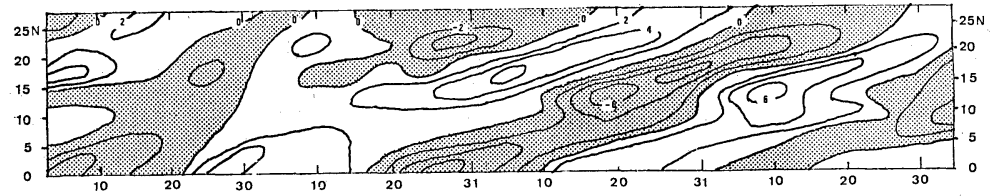

(b)

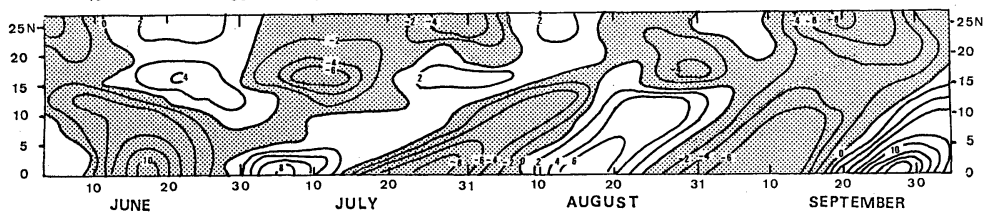

Fig. 9 Cross sections of the filtered wind component along the line shown in Fig. 1 at (a) $850 \mathrm{mb}$ (b) $200 \mathrm{mb}$. Contour interval is $2 \mathrm{~m} / \mathrm{sec}$ and negative areas are shaded.

from the south to the north. In the equatorial zone the maximum lower westerly (or easterly) and the maximum upper westerly (or easterly) are well in phase each other. During the northward propagation of the anomaly system some phase lag seems to appear between the two levels. To the north of central India (about $15^{\circ} \mathrm{N}$ ) the upper level anomaly seems to show 'no systematic propagation (or preferably to show standing oscillation), while the lower level anomaly still propagates northward. This may suggest that the vertical structure of the wind field gradually changes during the northward shift of the anomaly circulation regime.

\section{c) Vertical structure of the wind fluctuation over Trivandrum}

As mentioned already, the wind field over Trivandrum is considered to represent the fluctuations of both the southwest monsoon flow in the lower troposphere and the easterly jet in the upper troposphere (refer to Fig. 8(a)). In this subsection, the vertical structure of the wind fluctuation will be examined on the periodicity of 40 days. The vertical time cross-sections of the filtered zonal and meridional wind component are shown in Fig. 10. A quite different feature of fluctuation is found in the zonal and meridional wind component. In the fluctuation of the zonal wind component, a downward phase movement of anomaly wind is apparent with the maxima (or minima) in both $200 \mathrm{mb}$ (or higher) and around $700 \mathrm{mb}$ levels. It should be noted, however, that the actual mean zonal wind is westerly in the lower half and easterly in the upper half troposphere. That is, the wind regime is different between the lower and upper half troposphere. Additionally, if we take account of the Hadley type circulation over India, it may be preferable to express that after the maximum westerly (or easterly) flow occurs in the lower level the maximum easterly (or westerly) counterflow appears about 10 days later in the upper level. It is well known that the "active" (or "break") phase of monsoon circulation regime over central or northern India (around $20^{\circ} \mathrm{N}$ ) is associated with the westerly maximum (or minimum) of the lower level monsoon flow. At the same stage, the upper level easterly wind over south India is also maximum (or minimum). The distribution of the zonal wind in Fig. 10 (upper) is consistent with the typical "active" and "break" phases mentioned above. It also seems that the altitude level of the maximum zonal wind in the lower-half troposphere changes in the course of the seasonal march from June to October. The time crosssection of the meridional wind (Fig. 10, lower) clearly shows that the wind regime of this period range in the upper and lower half troposphere is different each other. The upper wind regime shows a feature of the prominent upward phase tilt while the lower one shows the downward phase tilt.

In the lower level the variance of the anomaly wind depend mostly on the zonal wind component. In the upper level, in contrast, the meridional wind component is relatively large compared to the lower level, which is also seen in the power density as shown in Fig. 8(a). It is of interest that in the upper level (especially at $200 \mathrm{mb}$ ) the maximum northerly (or southerly) wind appears about $90^{\circ}$ out of phase with the westerly (or easterly) maxima. That is to say, the anomaly wind vector related to the 40-day period shows a clockwise rotation at the easterly jet core level. At around 300 to $400 \mathrm{mb}$ level, on the contrary, the maxima of westerly (or easterly) and the maxima of northerly (or southerly) are roughly correspondent in their phases each other, which means the anomaly wind vector alternates its 

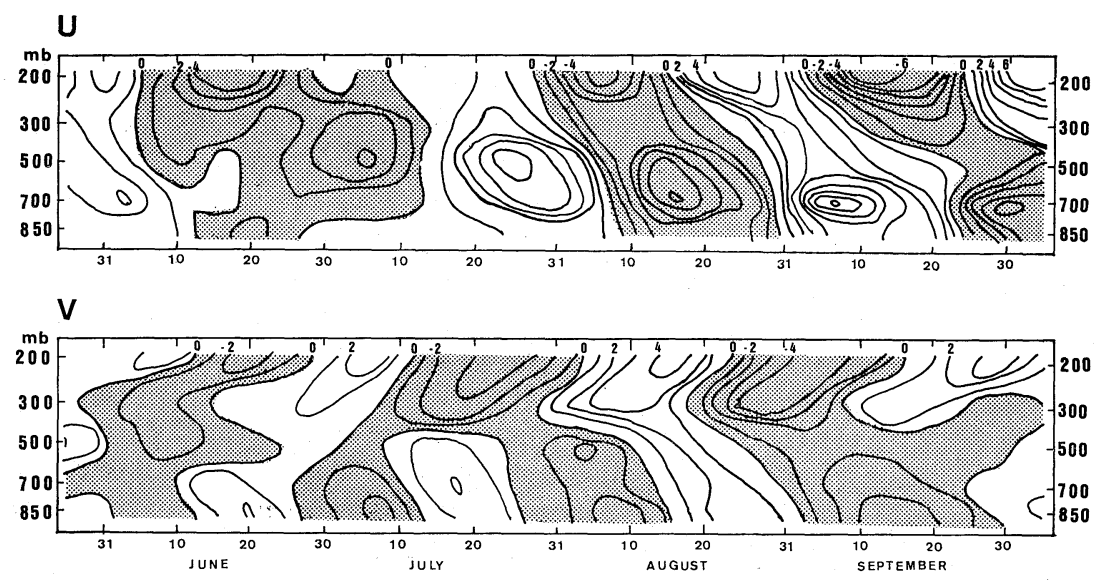

Fig. 10 Vertical cross sections of the filtered zonal (upper) and meridional (lower) wind component over Trivandrum. Contour interval is $1 \mathrm{~m} / \mathrm{sec}$, and negative areas are shaded.

direction from NW (SE) to SE(NW) abruptly.

A clockwise rotation of the anomaly wind vector may remind us of the effect of the BruntDouglas' issalobaric wind tending to adjust the standing oscillation of the geopotential field between the areas over Indian subcontinent and the Indian Ocean, as referred to Fig. 7. However, a rough estimation by using the geopotential data of $200 \mathrm{mb}$ level at Vishakhapatnum, Madras and Trivandrum suggested that the magnitude of the issalobaric wind is too small to explain the total variance of the actual meridional wind component. It is more probable, therefore, that the clockwise rotation of the wind vector is resulted from the northward movement of the anomaly circulation regime. Additional discussions will be made later.

\section{Composite time-space structure of the 40-day period over India}

In this section, we will discuss the composite time-space structure of the fluctuation of the 40 -day period, especially along the meridionalvertical plane over India. The inter-level crossspectral analysis was applied to verify the relative phase relationships among the geopotential, temperature, wind and moisture fields of different altitude levels, and cloudiness. The data at Trivandrum, Calcutta and Nagpur are again chosen respectively as representative points of southern, central India and northern India (or monsoon trough area). The relative phase relations of the 40-day period among the maxima (or minima) of different elements were calculated at these three stations with reference to the wind at 850 $\mathrm{mb}$ or $700 \mathrm{mb}$ level. Then, the relative phase positions of the maxima (or minima) of zonal wind, geopotential, temperature and humidity are rearranged with reference to the maximum cloudiness, to exhibit distinctly the difference of the time-spatial structure related to the "active" or "break" phase of each station. The result for each station is shown in Fig. 11.

As mentioned previously, the phases of the geopotential and zonal wind fluctuations of this period range at the lower troposphere show distinct northward movements (refer to Fig. 5 and Fig. 9). Henceforth, the difference of the verticaltime structures of several elements at the three stations from south to north can be identified as the transformation process of the space structure accompanied by the northward phase movement of the maximum (or minimum) cloudiness. At Trivandrum, the phases of the temperature field at each level changes from the lower to the upper level. At the maximum (or minimum) cloudiness the warm (or cold) core exists at the lower level (more than $850 \mathrm{mb}$ ), but the middle troposphere (700 to $300 \mathrm{mb}$ ) is just at the boundary from cold (or warm) to warm (or cold) air, and the cold (or warm) core is apparent at $200 \mathrm{mb}$ level. The vertical trough (or ridge) line is located near the cold (or warm) maximum (or minimum) of the middle troposphere. In contrast. at Nagpur the maximum cloudiness is accompanied by the cold core in the lowermost troposphere $(850 \mathrm{mb}$ level) and the relatively warm air above it. The maximum westerly and trough line in the lower troposphere are also followed almost in phase with the maximum cloudiness. Unlike the case 
TRIVANDRUM

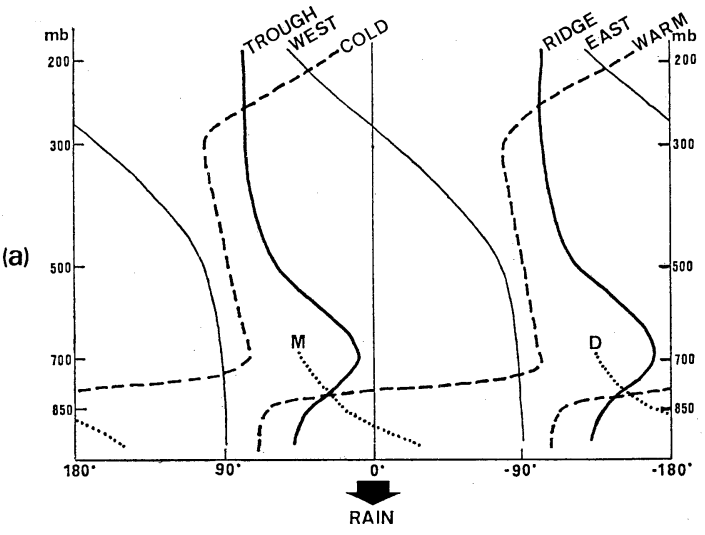

NAGPUR

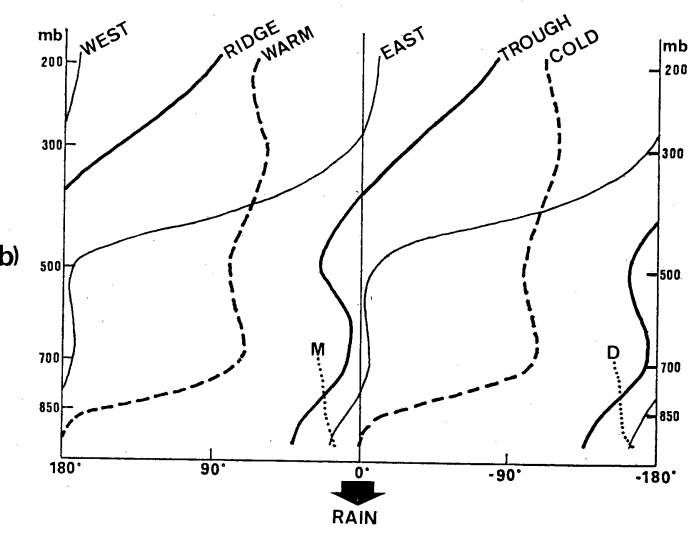

CALCUTTA

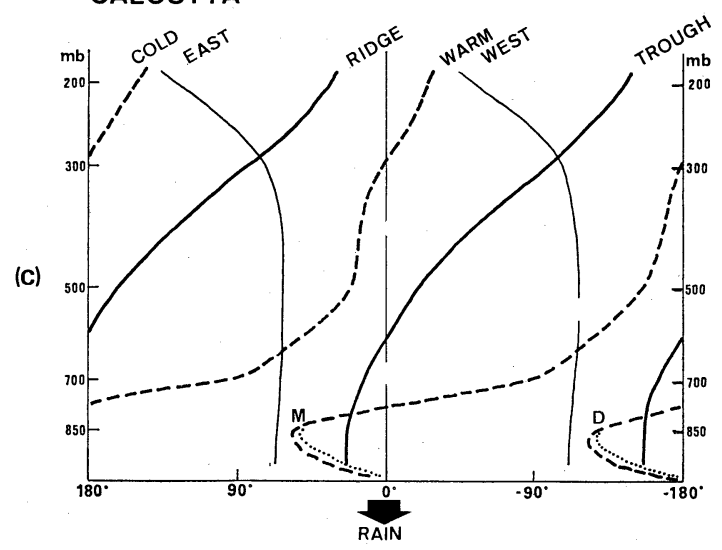

Fig. 11 Vertical structures of the geopotential height (thick solid lines), zonal wind component (thin solid lines), temperature (dashed lines) and moisture (dotted lines) for the 40-day period in reference to the maximum cloudiness over (a) Trivandrum (b) Nagpur and (c) Calcutta. at Trivandrum, the maximum cloudiness exists under the minimum zonal wind (the strongest easterly wind) in the upper troposphere. At Calcutta the feature of the temperature and geopotential field is similar to Nagpur, but the penetration of the cold (or warm) air under the warm (or cold) air becomes more distinct at the maximum (or minimum) cloudiness stage. In addition, the trough in the lower level is clearly coupled with the ridge in the upper level at the maximum cloudiness stage. That is, the air column is warmest at this stage. The zonal wind at the maximum (or minimum) cloudiness is intermittent or weak easterly in the lower level, probably because the westerly flow is forced to change to the easterly around here by the effect of the orography of the Arakan and the Himalayas. At each station the phase of the maximum (or minimum) moisture at the lower troposphere is roughly in phase with the maximum (or minimum) cloudiness.

As commented already, the periodicity of about two weeks dominantly appears over the monsoon trough resion. Here, we will compare the structure of the 40-day period with that of the about two weeks (13.3 days). Fig. 12 shows the composite structure of the 13.3-day period over Calcutta. A salient feature is the vertically-standing trough (or ridge) line, while that of the 40-day period shows the (southward) tilting (refer to Fig. 11(c) ). It is noteworthy that the composite structure of the 13.3-day period is comparable totally to the synoptic structure of the monsoon depression analyzed by Krishnamurti et al. (1975). For example, the cold core is apparent below $500 \mathrm{mb}$ and there is a reversal of thermal struc-

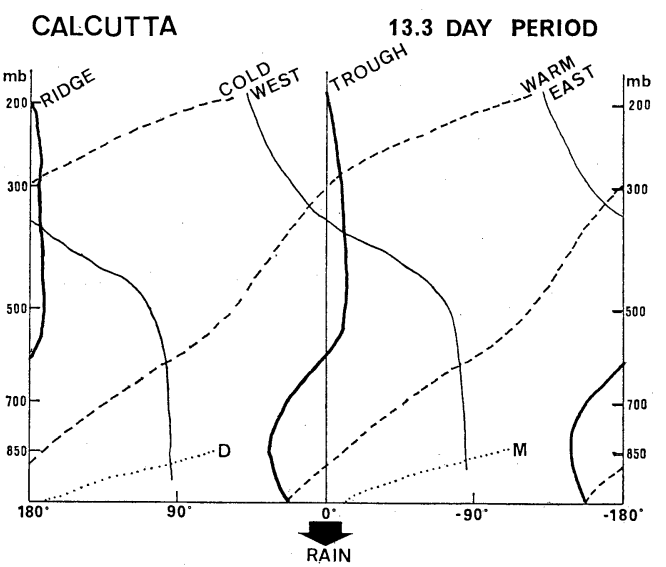

Fig. 12 Same as Fig. 11 but for the 13.3-day period over Calcutta. 
ture above that level. They pointed out that the influence of the storm in the vertical structure of the zonal wind is noted up to $400 \mathrm{mb}$. Fig. 12 suggests the similar result to their description. Since the easterly wind is dominant in the mean field above $300 \mathrm{mb}$, the westerly anomaly wind of these levels over the trough may represent the relatively weak easterly wind over there. Besides most of the minimum phases of $850 \mathrm{mb}$ height anomaly for the biweekly mode (see Fig. 5(c)) embed respectively one monsoon depression. Howver, the phase lag relation of the same height anomaly (refer to Fig. 6) suggests that the horizontal scale of the biweekly mode $(\simeq 10,000 \mathrm{~km})$ is far larger than that of one monsoon depression $(\simeq 2,000 \mathrm{~km}$ ). Some other studies (Krishnamurti et al., 1977; Krishnamurti and Ardanuy, 1980) presented the evidences that this mode is attributed to the westward propagating waves with the scale of $8 \sim 10,000 \mathrm{~km}$. Murakami (1976) also pointed out that this mode is of large space scale covering the whole area over the Bay of Bengal, Indian subcontinent, Indo-China and Tibetan Plateau. It is sufficient, therefore, to understand that the composite structure in Fig. 12 may represent the structure of some kind of wave or oscillation of large scale oriented along the line from IndoChina via the Bay of Bengal toward the monsoon trough area embedding one monsoon low or depression in each cycle. As commented already, however, whether each storm may develop to the monsoon "depression" or may remain at the monsoon "low" stage seems to depend principally on the 40-day period oscillation.

We can notice some apparent change of the vertical structures, especially of the geopotential and temperature field from the south to the north. Most remarkable change is a reversal of the temperature anomaly at the lower and upper troposphere from southern India (Trivandrum) to central and northern India (Nagpur and Calcutta). The trough-ridge line throughout the troposphere also shows gradual southward tilting to the higher level, and finally over the monsoon trough region the lower trough is coupled with the upper ridge. This stage is identified as the most active phase of monsoon over India with the well-established Tibetan High and the intense monsoon trough. That is, at the maximum cloudiness stage the upper level cold trough over southern India changes to the warm ridge over central and northern India, while the lower level warm trough changes to the cold trough. Since the upper level warm ridge over central and northern India may be formed by the upward transport of latent heat by cumulus convection, it is suggested that the cumulus convection is gradually enhanced from the south to the north with the northward shift of the maximum cloudiness as shown in Fig. 3.

Here, the divergence field was estimated for each altitude level over the square region by using the zonal and the meridional wind data of the four stations at central India (Nagpur, Bombay, Bangalore and Vishakhapatnum). The areal mean divergence was computed following the Gauss' theorem:

$$
[V \cdot V]=\frac{1}{S} \oint V_{n} d l=\frac{1}{S}\left(\sum_{i=1}^{4} \int V_{n i} d l_{i}\right)
$$

where $\mathrm{S}$ is the area of the square, $V_{n}$ the wind vector component normal to a side of the square, $V_{n i}$ the mean of $V_{n}$ at two stations for $i$ th side, and [ ] denotes the areal mean. To reduce the observational error, the smoothed wind data of 5-day running average were adopted. The cross spectra between the divergence for each level and the areal mean geopotential height and cloudiness were, then, computed. Fig. 13 indicates the phase diagram in reference to the trough at 850 $\mathrm{mb}$ obtained for the 40-day period. The trough (or ridge) of $850 \mathrm{mb}$ corresponds well with the maximum convergence (or divergence) in the lower-half troposphere and with the maximum divergence (or convergence) in the upper half troposphere. This implies that the maximum cloudiness over central India represents the maximum upward motion in the whole troposphere

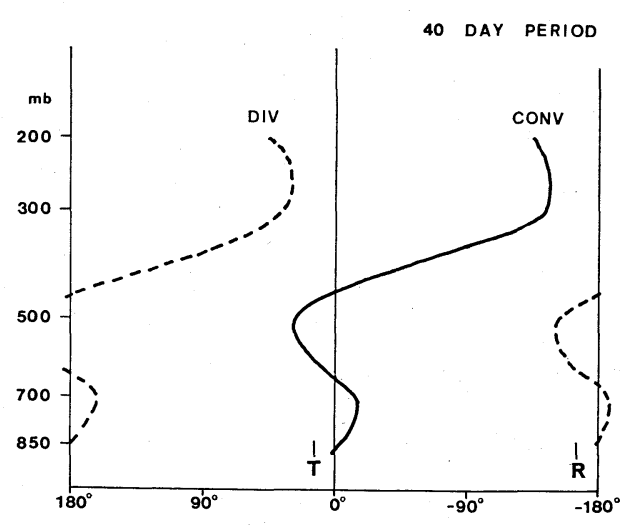

Fig. 13 Vertical structure of the divergence field over central India (the area encircled by Nagpur, Bombay, Bangalore and Vishakhapatnam) for the 40-day period. The position of the $850 \mathrm{mb}$ trough (and ridge) at nearly the center of the area is also indicated. 


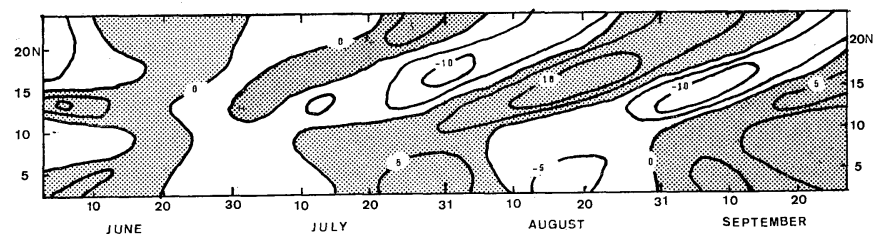

Fig. 14 Cross section of the filtered zonal wind shear along the line shown in Fig. 1. Contour intervals is $5 \mathrm{~m} / \mathrm{km}$ and negative areas are shaded.

relevant to this periodicity. These features suggest that the conversion from available potential energy to kinetic energy $\left(\omega^{\prime} T^{\prime}<0\right)$ in the middle and upper troposphere gradually increase in the course of northward shift of the maximum cloudiness and may reach its maximum over central India through the monsoon trough region. The appearance of the low level cold core at the maximum cloudiness may also be an evidence for the dominancy of cooling effect of raindrop evaporation resulted from the enhanced cumulus convection.

As mentioned above, the composite vertical structure of temperature, geopotential and wind field for the 40-day period is modified drastically from the south to the north over India by deepening and enhancement of cumulus convection. It may be speculated that the northward shift is mainly attributed to the northward shift of the maximum monsoon flow in the lower level. It is sure that the maximum cloudiness is well in phase with the maximum westerly wind in the lower level (i.e., monsoon flow) at central India (Nagpur). The maximum cloudiness at southern India (Trivandrum) is, however, about $90^{\circ}$ out of phase with the maximum westerly (namely at the transitional stage from the easterly to the westerly). This may suggest that not only the strength of convection but also the physical process which induces the cloudiness (or rainfall) is different each other over southern India and over central or northern India. A brief consideration will be made here on the actual process related to the 40-day period. It is well known that during the monsoon season over India especially over central and northern India the atmosphere of the lower level is conditionally unstable in a mean state (e.g., Krishnamurti and Bhalme, 1976, etc.). A penetration of relatively moist air into the lower troposphere by the southwest monsoon flow over the Indian subcontinent will cause the intensification of moist static instability. The shallow convection by daily heating near the ground could be a trigger to release the increased moist static instability to develop deeper convections. However, if we review the satellite cloud pictures for individual days, it seems that the cloudiness fluctuation of the time scale treated here appears as the slow northward shift of the main route of successively passing cloud clusters with the horizontal scale of about 500 to $1,000 \mathrm{~km}$ or more. The category of cloud clusters here includes monsoon lows or depressions passing from the Bay of Bengal through northern India as well as eastward traveling cloud disturbances crossing over the equatorial Indian Ocean and southern India.

Consequently, as for the alternation of monsoon activity of around 40-day period, we should not take account of a simple process of cumulus convection by releasing conditional instability but the process of large scale upward motion such as the CISK mechanism. It would be worthwhile to state that the anomaly of zonal wind shear at $850 \mathrm{mb}$ shows a northward movement as shown in Fig. 14.

The low-level convergence necessary for initiating the CISK mechanism may be provided at the stage of maximum cyclonic shear. Actually, the anomaly cyclonic shear is in good agreement with the anomaly positive cloudiness in Fig. 3. It is of interest that the maximum stage of anomaly cyclonic shear tends to occur at about $15^{\circ} \mathrm{N}$ and secondly at $0^{\circ}-5^{\circ} \mathrm{N}$ region. The former region may correspond with the cyclogenesis area of monsoon lows and depressions over the Bay of Bengal, and the latter region is associated with the main passage of the eastward moving disturbances over the equatorial zone. It was already pointed out (Yasunari, 1979) that the development of the equatorial disturbances has an important role to initiate the northward shift of the cloudiness of the 40-day mode. The vertical structure at the maximum cloudiness over Trivandrum, therefore, may be affected by the equatorial disturbances passing over there or to the south of it. 


\section{Some considerations on the equatorial disturb- ance and the Southern Hemisphere circulation}

It is of interest to note that in Fig. 3 the maximum (or minimum) cloudiness over the equatorial zone occurs well in phase with the maximum (or minimum) cloudiness in the Southern Hemisphere where nearly-standing oscillation is dominant over the area from the equator to $30^{\circ} \mathrm{S}$. This may suggest that the formation or development of the major equatorial cloud disturbances over the Indian Ocean is closely linked with the mid-latitude westerly disturbances and/or fronts in the Southern Hemisphere which affect even the equatorial zone.

To verify the influence of the Southern Hemisphere circulation on the equatorial disturbances, the time series of some elements at Gan Island $\left(0^{\circ} 41^{\prime} \mathrm{S}, 73^{\circ} 09^{\prime} \mathrm{E}\right)$ over the equator and Tananarive $\left(18^{\circ} 54^{\prime} \mathrm{S}, 47^{\circ} 32^{\prime} \mathrm{E}\right)$ at Madagascar Island were examined. Fig. 15 shows that the maximum cloudiness (associated with the eastward moving disturbances) and the maximum zonal wind cyclonic shear over the equator occur at the minimum stage of the geopotential height and temperature at $500 \mathrm{mb}$. The geopotential height showed nearly the same tendencies throughout the troposphere, which is also the case with Trivandrum. In addition it should be noted that the tendency at $500 \mathrm{mb}$ over Gan is highly correlated with that of the temperature over

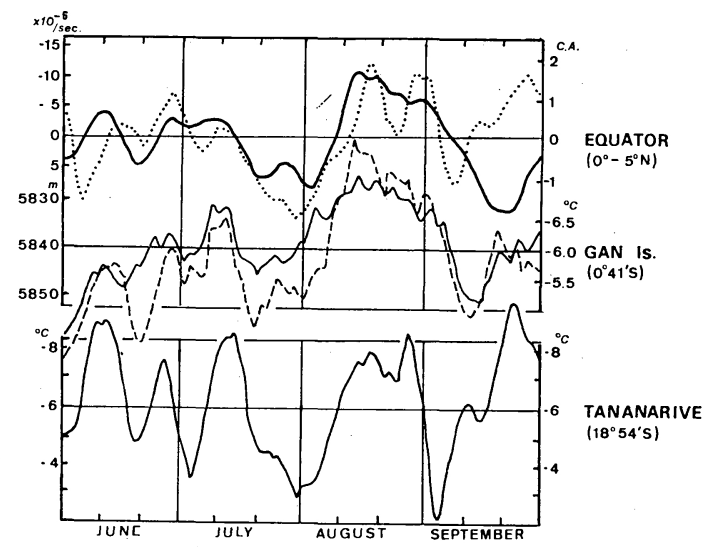

Fig. 15 Time series of filtered cloudiness (thick solid line) for the 40-day period, zonal wind shear (dotted line) over the equatorial zone $\left(0^{\circ}-5^{\circ} \mathrm{N}\right)$, temperature (solid line) and geopotential height (dashed line) at $500 \mathrm{mb}$ over Gan Island, and temperature at $500 \mathrm{mb}$ over Tananarive (solid line). Note that all the data except for the cloudiness are smoothed with 7-day running mean and are plotted upside down.

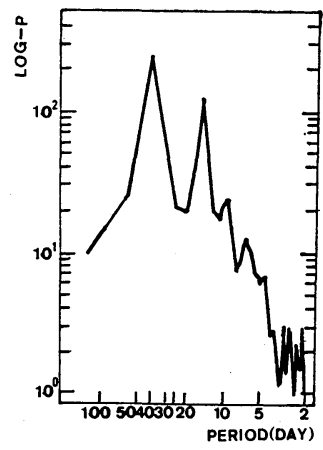

Fig. 16 Power spectra of the temperature at $500 \mathrm{mb}$ over Tananarive by using MEM method. Units are $\left({ }^{\circ} \mathrm{C}\right)^{2} \bullet$ day.

Tananarive, which has the predominant periodicity of the 40 days as shown in Fig. 16. That is, the formation or development of the major equatorial disturbances related to the 40-day period seems to be triggered by the cold air penetration in the middle (and maybe the upper) troposphere from the Southern Hemisphere subtropics.

Here, in order to examine the long-term fluctuation $(>10$ days period) at the Indian Ocean sector, the cross section of smoothed $500 \mathrm{mb}$ height for the mid-latitudes along $50^{\circ} \mathrm{E}$ is composed as shown in Fig. 17. The perturbation shows a distinct time scale of 30 to 40 days especially at $20-30^{\circ} \mathrm{S}$ zone and the maxima of cold stage at Tananarive (shown with the white arrows in the figure) from May to October are well correspondent with the trough of around $20^{\circ} \mathrm{S}$. It also seems that the regional index (as supposed in the intervals of the contours between $30^{\circ} \mathrm{S}$ and $50^{\circ} \mathrm{S}$ ) has the same periodicity and that the cold stage coincides with the low index phase.

Thus, we may speculate that the fluctuation of monsoon cloudiness with the 40-day period is closely linked with the cold air outbreak associated with the large scale fluctuation of the westerly wave movements in the Southern Hemisphere. Unfortunately, only a few studies have been made on the large-scale perturbations of the Southern Hemisphere mid-latitude circulation including the consideration of time scales, mostly because of the insufficiency of the data. Anderssen (1965) analized the long waves of wave number 1 to 6 by using the $500-\mathrm{mb}$ geopotential data. He commented that the waves of wave number 1 is quasi-stationary in a rough sense but its most frequent phase velocity at 


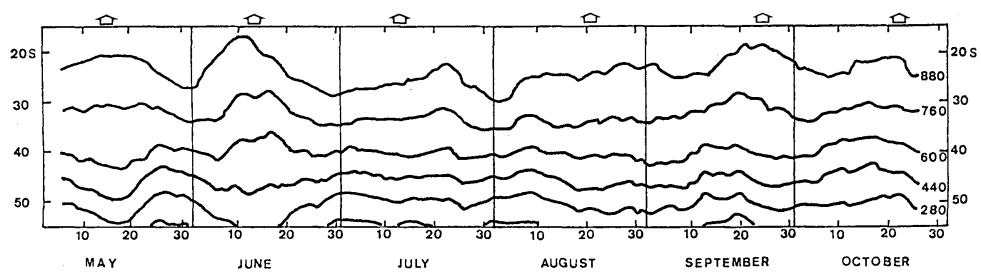

Fig. 17 Cross section of the geopotential height at $500 \mathrm{mb}$ along the line of $50^{\circ} \mathrm{E}$. The data are smoothed with 9-day running mean. The phases of minimum temperature at $500 \mathrm{mb}$ in the 40-day period over Tananarive are also shown with the white arrows.

$50^{\circ} \mathrm{S}$ is nearly $10^{\circ}$ longitude per day. This implies that the transient part of wave number 1 has the inherent periodicity of 30 to 40 days. $\mathrm{He}$ also noticed that there is some relationship between the amplitude variation of the wave number 1 and the development of cut-off lows over south Africa. Kao et al. (1970) made analysis of the kinetic energy of large-scale motion in wave number-frequency space. Though they did not stress the dominant periodicities of each wave mode, their results show that the zonal and meridional kinetic energies of the longest waves (wave number 1 to 3$)$ at the higher latitude $\left(60^{\circ} \mathrm{S}\right)$ seems to concentrate at the spectral band of 30 to 50 day period especially in winter season. By utilizing the EOLE satellite data set. Webster and Keller (1974, 1975) found the dominant periodicity of 18-23 days in zonal indices, momentum flux and mean and perturbation kinetic energies at $200 \mathrm{mb}$ level. However, their results on the wave number-frequency domain also suggest the existence of longer period ( $>30$ days) especially for ultra long waves (wave number 1 and 2). At all events, conclusive results have not yet been obtained on the time-space characteristics of the mid-latitude circulation in the Southern Hemisphere.

The difference of the synoptic situation of the Southern Indian Ocean between the maximum cloudiness (i.e., formation of cloud disturbances) and the minimum cloudiness (i.e., no formation of cloud disturbances) over the equatorial zone can be seen contrastively in the satellite pictures as shown in Fig. 18. The successive 4 days during the maximum cloudiness stage (Aug. 1619) and the minimum stage (July 21-24) were selected by referring to Fig. 15. In Fig. 18(a) cloud clusters (with the scale of $500-1,000 \mathrm{~km}$ or more) are continuously formed and developed over the equatorial zone $\left(0^{\circ}-10^{\circ} \mathrm{S}\right)$, while in Fig. 18 (b) cluster formation is rarely seen. It should be noted that cold fronts (or frontal zones) are elongated toward the equator in Fig. 18(a), while they are relatively short and are limited in the mid-latitudes in Fig. 18(b). The occurrence of cellular convective clouds is noticeable over a broad area at the back side of the fronts in Fig. 18(a), but it is not seen or is limited in a small area in Fig. 18(b). These features suggest that at the maximum cloudiness stage (Fig. 18(a)) the cold air outbreak from the polar region toward the tropics is remarkably associated with the extended trough of the westerly waves, while at the minimum stage (Fig. 18(b)) the cold air mass is not strong and the westerly waves are confined within the mid-latitudes. In other words, the maximum cloudiness stage may correspond with the low index phase, and the minimum cloudiness stage the high index phase of the westerly waves, respectively.

The increase of convective instability by the penetration of cold air in the middle (and upper) troposphere over relatively warm and moist air may facilitate the development of disturbances. In addition, it is strongly suggested from Fig. 18(a) (especially from the case for August 16 and 18) that some dynamical interaction between the extended troughs (or fronts) and the equatorial waves may be important for the formation and development of disturbances. The equatorial disturbances once developed may trigger the northward shift of monsoon cloudiness during the eastward propagation along the equator. More discussion on this process will be made later.

Although the analysis made in this section is still preliminary, it is tempting to say that the major cold air outbreak toward the lower latitudes associated with the index cycle (or vacillations) of the mid-latitudes in the Southern Hemisphere should be a pace-maker of the 40day period in the monsoon activity. 
(a)
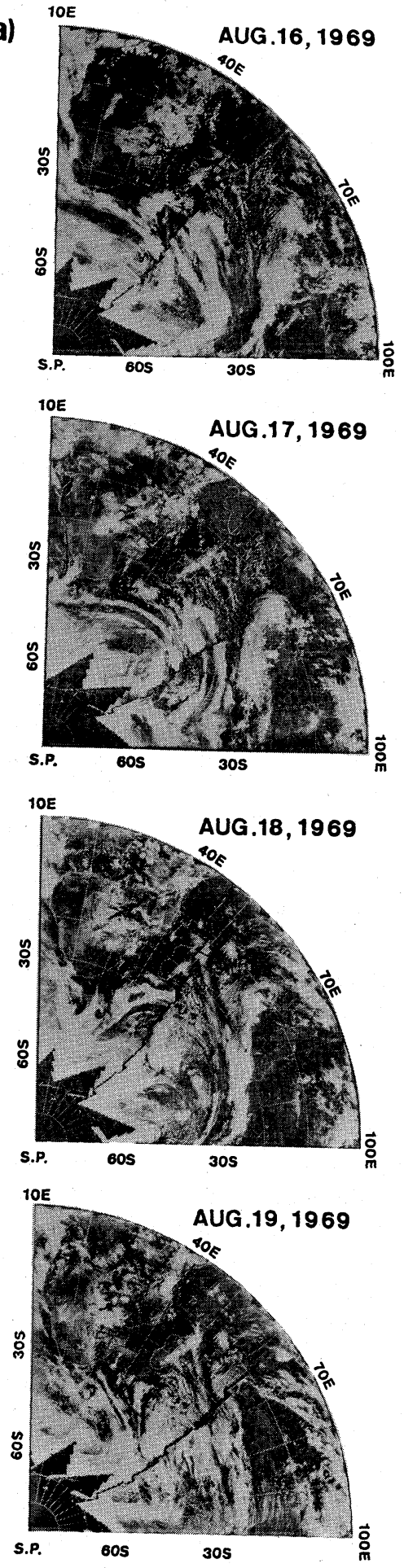

(b)
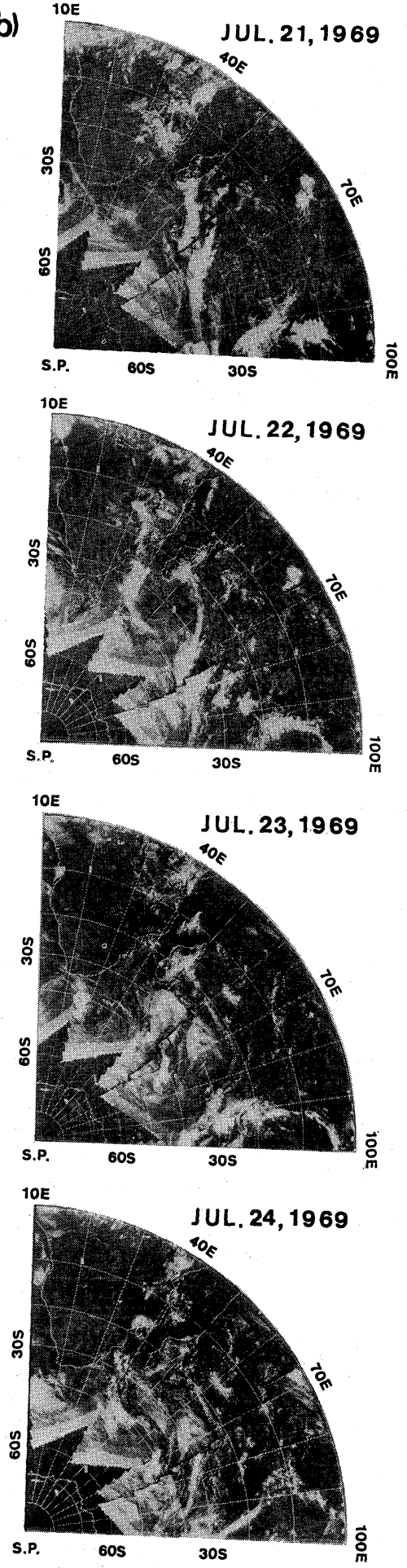

Fig. 18 Quadrant mosaic pictures (ESSA 9, visible) of the southern hemisphere over the Africa-Indian Ocean sector for the period of (a) the maximum cloudiness (Aug. 16-19) and (b) the minimum cloudiness (July 21-24) over the equator. 


\section{Discussion}

The mean monsoon circulation over Indian Ocean through the Asian continent is considered to be a northward-extended local Hadley cell of the Southern Hemisphere. The branch of the downward motion may be located at the subtropical high zone over the southern Indian Ocean, and that of the upward motion may be at the major summer monsoon area centered over northern India through the Himalayas. These two branches are connected each other by the cross-equatorial monsoon flow in the lower troposphere and the easterly jet in the upper troposphere.

However, it was revealed that the major active-break cycle of monsoon activity occurs with the 40-day period associated with the northward movement of the maximum (or minimum) cloudiness from the equatorial zone, and that the atmospheric structure over India shows a prominent change especially in the geopotential and temperature field in the course of the northward movement of the cloudiness. This oscillation was also supposed to be triggered through the formation of the equatorial disturbances by the outbreak of the cold air mass followed by the major trough of the mid-latitude westerly waves in the Southern Hemisphere.

Taking account of the total aspect mentioned above, one schematic model of the anomaly Hadley regime is proposed as a working hypothesis associated with the active-break cycle of about 40-day period. The model shows a multicell structure along the meridional section from the Himalayas to the sub-tropical high area over the Indian Ocean. The four stages of the oscillation are illustrated in Fig. 19, in the order as $\mathrm{A} \rightarrow \mathrm{B} \rightarrow \mathrm{C} \rightarrow \mathrm{D}$ and again from $\mathrm{D}$ to $\mathrm{A}$ cyclicly. When the cold air outbreak occurs over the Southern Hemisphere (refer to stage A), the equatorial disturbance is formed near the head of the cold air mass. At this stage, the whole of India except the foot of the Himalayas is dominated by the "break" condition with the maximum downward motion over central India. At stage B the "break" condition over central India still continues while a part of upward motion of the Southern Hemisphere cell is approaching to southern India. The equatorial disturbance is, on the other hand, moving eastward during the stage from A to B. As pointed out previously (Yasunari, 1979), this eastward moving disturbance may be closely connected

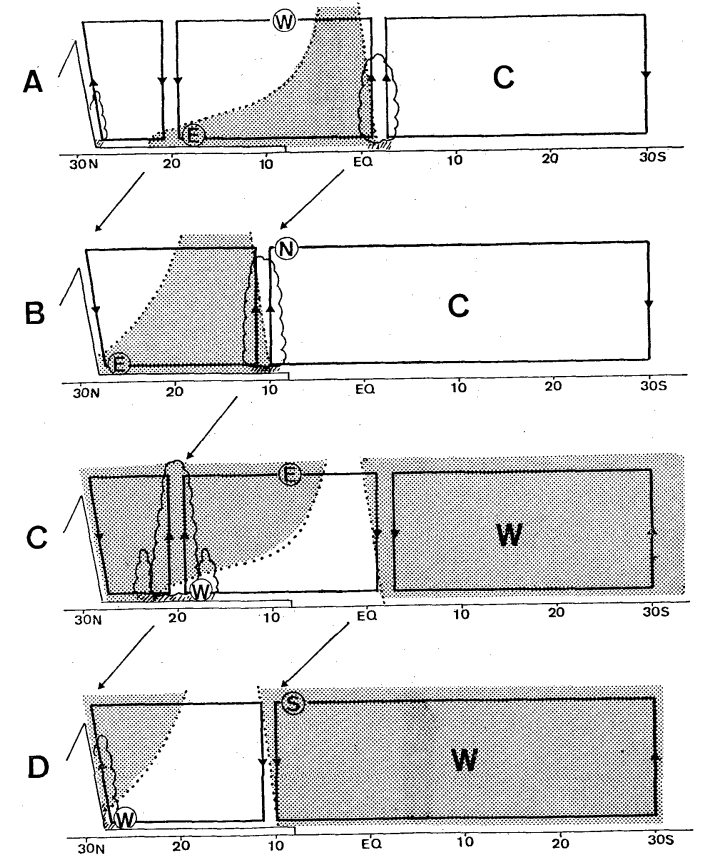

Fig. 19 Schematic model of the 40-day period oscillation of the anomaly Hadley circulation. The maximum stage of the anomaly wind directions are indicated in the circles. Relatively warm areas are shaded.

with that described by Madden and Julian (1971, 1972), which has a strong zonal circulation cells to the east and west of it. It is plausible, therefore, that as well as the intensified southern Indian Ocean high the development of the disturbance over the eastern half of the equatorial Indian Ocean may cause the strengthening of the southwest monsoon flow over the Arabian Sea side.

The cumulus convection may be intensified during the northward shift of the upward portion and may reach its maximum at around $20^{\circ} \mathrm{N}$ (near the monsoon trough region) as shown at stage C. During the stage from B to $C$ the southwest monsoon flow may reach its maximum and bring about the maximum rainfall over the west coast of India. The cold core will gradually appear into the lower troposphere by the cooling of rainfall, while the warm air will gradually spread over it by latent heating. Thus, at stage $C$ the upper tropospheric warm anticyclone over central (or northern) India may become most intensified. At nearly the same time (stage C) the less-disturbed high-index type circulation with a relatively warm air may be dominated over the Southern Hemisphere, as noticed in 
Fig. 3 and Fig. 17. This implies that at the mature stage of the active monsoon the southwest monsoon flow in the lower level has already gone down in its source region. At stage $\mathrm{D}$ the area of the maximum convection shift to the Himalayas, while the "break" condition again spreads over the whole of India and the equatorial zone, but this stage will move to stage A when the next cold air outbreak occurs in the Southern Hemisphere.

It may be reasonable to say that the clockwise rotation of the anomaly upper wind vector over Trivandrum (or the easterly jet core region) as shown in Fig. 10 is attributed to the northward shift of the cells. That is, when the upward portion (maximum cloudiness) of the anomaly cell is located near the equatorial zone such as stage B and D in Fig. 19, the effect of the coriolis force is relatively small. But when the cell is located over higher latitude such as stage $A$ and $\mathrm{C}$, the effect is relatively large. As a result, the meridional circulation regime may have less zonal component of wind over the equatorial zone, and reversely more zonal component over the higher latitudes.

It is well known that at the "break" period over central India the monsoon rainfall increases over the equatorward region and the foot area of the Himalayas. This situation is well correspondent with stage A. Additionally, it is suggested that the intensities of the convection (and rainfall) of these two areas may be different each other at the individual stage from.D to B. Namely, when the equator side is more active in rainfall, the Himalayan side will be less active, and vice verse. This phenomenon has been recently noticed observationally (Riehl, 1979).

Thus, the model of multicell structure presented here could explain many aspects of the activebreak cycle of the monsoon activity with about 40-day period over and around India, though some problems may still be reserved. Interestingly, a similar multicell structure was presented in the numerical simulation of the mean monsoon circulation and its temporal variation (viz., activebreak cycle), only when the effect of orography of the Himalayas is included in the model (Hahn and Manabe, 1975). This may imply, in other words, that the structure of the meridional circulation as shown in Fig. 19 should be most apparent along the longitudes of the HimalayaTibet region (about $70-100^{\circ} \mathrm{E}$ ). In fact, the timelatitude sectional analysis of cloudiness along the different longitudinal sectors (Yasunari, 1979) offered an evidence for this idea.

The active-break cycle with around the 40-day period should be compared in the process and spatial structure to that of the winter monsoon with the 20-30 day period over east and southeast Asia studied by Murakami (1979). He commented that there exists a marked periodicity of 20-30 days in the cold air bursting out of the Siberian high and associated temperature oscillation over the east China sea is nearly in phase (vertically) within the atmospheric layer from the surface to $500 \mathrm{mb}$ (or even higher) but the oscillation over the south China sea exhibits a large vertical phase difference between the lower (below $850 \mathrm{mb}$ ) and upper (above $500 \mathrm{mb}$ ) troposphere. The structure change from the north to the south mentioned above seems to resemble quite well with that of the 40-day period from the south to the north, but a distinctly different situation of the summer monsoon oscillation from that of the winter monsoon may be an existence of the equatorial disturbances as a medium of the interaction between the two hemispheres.

The maximum cloudiness (viz., the upward portion of the anomaly cells) seems to correspond with the maximum cyclonic shear zone in the lower troposphere. In this respect, a northward shift of the cloudiness may be considered as a northward shift of the convergence zone (or ITCZ). In connection with the mechanism of the "northward shift", Webster and Chou (1980) suggested in the numerical model the possibility of the feedback process between the hydrologic cycle and the differential heating between the ocean and the continent although their simulation was focused to the biweekly mode oscillation. However, it is noteworthy to state that the type of disturbances seems to be different each other over the equatorial zone $\left(10^{\circ} \mathrm{S}-10^{\circ} \mathrm{N}\right)$ and over central and northern India $\left(10^{\circ}-30^{\circ} \mathrm{N}\right)$ although the cloudiness (or rainfall) shifts northward continuously from the equator to the Himalayan side. As mentioned already, the condition for the development of equatorial disturbances may be provided by the cold air penetration from the Southern Hemisphere associated with the increase of the cyclonic shear flow. Some recent preliminary surveys of the summer MONEX 1979 have revealed that the cyclonic vortex (or the synoptic-scale disturbance) over the south Arabian Sea embedded in the strong cyclonic shear zone has an important role on the onset of the monsoon over India. Furthermore, it has been strongly suggested that this 
"onset vortex" may be formed through the barotropic instability process (e.g., Krishnamurti et al., 1980; Kuettener and Unninayar, 1980). This process may be feasible even for the formation of the equatorial disturbance related to the activebreak cycle of the monsoon, though the convectively unstable condition by the cold air penetration to the middle (and upper) troposphere may also be necessary. Over central and northern India, on the contrary, the cloudiness may be majorly due to the monsoon depressions as described in section 3. Recent dynamical studies have revealed that the combined barotropic-baroclinic instability (Krishnamurti et al., 1976) and/ or the CISK-barotropic-baroclinic instability (Shukla, 1978) are important for the formation and growth of the monsoon depressions. Their studies also suggest that these instabilities are inherent over and around the monsoon trough region. That is, the type of dynamic instability for the development of disturbances seems to be replaced from southern India, to central and northern India, though a necessary condition for the full-development such as a sufficient moisture supply through the southwest monsoon flow may be preserved from the south up to the north. On the other hand, some former and recent studies noted the influence of the mid-latitude westerly waves of the Northern Hemisphere to the monsoon activity over India. Raman and Rao (1980), for example, pointed out that the "break" condition over central and northern India is closely linked with the circulation pattern of blocking ridge over east Asia coupled with the cold trough to the north of India. This condition may provide more convective precipitation (and cloudiness) over the Himalaya-Tibet region. Therefore, we are tempted to say that the activebreak cycle of the 40-day period associated with the northward transition of maximum cloudiness zone is resulted from a chain-interacting process of laterally coupled waves initially driven by the Southern Hemisphere westerly wave movements. At all events, further theoretical and observational studies will be required on the problem whether the active-break cycle of the monsoon discussed here is characterized as a free oscillation with some feedback system or as a forced oscillation by the extratropical influences.

From the point of view of long-range forecasting of the monsoon activity, the tendency of temperature field over the Southern Hemisphere associated with the large scale fluctuation of westerly waves should be noted more. This view- point may hold in the study of interanual fluctuation of monsoon activity over and around India. Hahn and Shukla (1976) stressed the negative correlation between the snow covered area over Eurasia in spring and the monsoon rainfall over India. However, Chang and Yasunari (1981) has recently noticed some relationships between the surface pressure patterns in the Southern Hemisphere and the monsoon rainfall over India. For example, in 1972, the severe drought year over India, a mean position of the southern Indian Ocean high (and may be related upper troposphere pattern) shift far eastward toward Australia with weaker intensity compared to normal years, while the spring snow covered area over Eurasia was also largely extended (Hahn and Shukla, 1976). Consequently, an abnormally severe drought (or flood) year of monsoon should be considered as a result of coupling with both the anomalous circulations over the Northern and the Southern Hemisphere.

\section{Concluding remarks}

Through the analysis of the geopotential and wind fluctuation during the summer monsoon season over and around India, the predominant periodicity of about 40 days was confirmed especially in the lower and upper troposphere as a major active-break cycle of the monsoon activity. As well as the cloudiness fluctuation of the same period (Yasunari, 1979; Yasunari, 1980), these elements except the geopotential height in the upper level showed a marked northward propagation from the equator toward the Himalayan region. The geopotential height at $200 \mathrm{mb}$ showed, in contrast, a standing oscillation over India. Cross-spectral analyses revealed that the vertical structure of the atmosphere is gradually modified during the northward phase shift of the anomaly cloudiness with the 40-day period. This modification is most apparent in the temperature field. The modification of the vertical structure from the south to the north over India seems to be attributed to the different degree of cumulus convection by different types of disturbances. It is also suggested that this cycle is caused by the periodical cold air outbreak over the middle and upper troposphere of the equatorial zone which may be associated with the index cycle of the westerly wave movements in the Southern Hemisphere. Finally, a multicell structure of the anomaly Hadley circulation regime was proposed, which gives reasonable interpretations on various aspects of the fluctua- 
tion of this mode.

As a next step, a more detailed observational and theoretical studies should be made on the process of interactions (including the energetics) among the Southern Hemisphere circulations, the equatorial disturbances and the monsoon activity. FGGE data and MONEX data now being processed are desirable for these studies. The relationship between the year to year fluctuation of the monsoon activity over Asia and that of the mid- and high-latitude circulation regime in the Southern Hemisphere will also be an interesting problem for future.

\section{Acknowledgements}

The author wishes to thank Prof. C. Nakajima for his constant encouragement and helpful advices throughout this work. $\mathrm{He}$ would also like to express his sincere appreciation to Prof. I. Hirota for many valuable comments during the course of completing this work and for his careful reading of the manuscript. He is greatly indebted to Dr. Ts. Nitta, University of Tokyo, and the other refrees for their constructive suggestions and advices on the revision of this paper. Thanks are extended to Prof. T. Watabe and Prof. Y. Takaya for their encouragements throughout the work. $\mathrm{He}$ is also grateful to Miss Y. Ishii and Mrs. T. Baba for typing the manuscript.

\section{References}

Alexander, G., R.N. Keshavamurty, U.S. De, R. Chellappa, S. K. Das and P. V. Pillai, 1978: Fluctuations of monsoon activity. Indian J. Met. Hydrol. Geophys., 29, 76-87.

Anderssen, E. C., 1965: A study of atmospheric long waves in the Southern Hemisphere. Notos, 14, 30-38.

Cadet, D. and P. Olory-Togbé, 1977: The propagation of tropical disturbances over the Indian ocean during the summer monsoon. Mon. Wea. Rev., 105, 700-708.

Chang, T. and C. Wang, 1976: A preliminary analysis about large-scale circulation of tropical area and its mid-range variation in summer season. Proc. Conf. Tropical Weather, 1-9 (in Chinese).

Chang, T. and T. Yasunari, 1981: (To be published.)

Hahn, D. G. and J. Shukla, 1976: An apparent relationship between Eurasian snow cover and Indian monsoon rainfall. J. Atmos. Sci., 33, 24612462.

and S. Manabe, 1975: The role of mountains in the south Asian monsoon circulation. J. Atmos. Sci., 32, 1515-1541.

Hamilton, M. G., 1977: Some aspects of break and active monsoon over southern Asia during summer. Tellus, 29, 335-344.

Kao, S. K., R. L. Jenne and J. F. Sagendorf, 1970: The kinetic energy of large-scale atmosphere motion in wavenumber-frequency space: II. Midtroposphere of the Southern Hemisphere. J. Atmos. Sci., 27, 1008-1020.

Krishnamurti, T. N., M. Kanamitsu, R. Godbole, C. B. Chang, F. Carr and J. H. Chow, 1975: Study of a monsoon depression (I) Synoptic structure. J. Met. Soc. Japan, 53, 227-240.

and - 1976a: (II) Dynamic structure. $J$. Met. Soc. Japan, 54, 208-225.

and H. N. Bhalme, 1976b: Oscillations of monsoon system. Part I, observational aspects. J. Atmos. Sci., 33, 1937-1954.

, J. Molinari, Hua-lu, Pan and V. Wong, 1977: Downstream amplification and formation of monsoon disturbances. Mon. Wea. Rev., 105, 1281-1297.

and P. Ardanuy, 1980: The 10 to 20day westward propagating mode and "Breaks in the Monsoon's". Tellus, 32, 15-26.

, P. Ardanuy, Y. Ramanathan and R. Pasch, 1980: On the onset vortex of the summer monsoons. FGGE Ope. Rep. Ser., 9, 115-166.

Kuettner, J. P. and M. S. Unninayar, 1980: The near-equatorial jet south of India and its role in the onset of the monsoon. FGGE Ope. Rep. Ser., 9. 96-114.

Madden, R. A. and P. R. Julian, 1971: Detection of a 40-50 day oscillation in the zonal wind in the tropical Pacific. J. Atmos. Sci., 28, 702-708.

$\longrightarrow$ and 1972: Description of global-scale circulation cells in the tropics with a 40-50 day period. J. Atmos. Sci., 29, 1109-1123.

Murakami, M., 1976: Analysis of summer monsoon fluctuations over India. J. Met. Soc. Japan, 54, 15-31.

Murakami, T., 1979: Winter monsoonal surges over east and southeast Asia. J. Met. Soc. Japan, 57, 133-158.

Rahmatullah, M., 1952: Synoptic aspects of the monsoon circulation and rainfall over Indo-Pakistan. J. Met., 9, 176-179.

Raman, C. R. V. and Y. P. Rao, 1980: Interaction of waves in middle latitude westerlies over Asia with the southwest monsoon over India. FGGE Ope. Rep. Ser., 9, 12-22.

Rao, Y. P., 1976: Southwest Monsoon. Synop. Met. No. 1/1976, Met. Mono. India Met. Dept. 107.

Riehl, H., 1979: Climate and weather in the tropics. Academic Press, 367-369.

Shukla, J., 1978: CISK-barotropic-baroclinic instability and the growth of monsoon depressions. J. Atmos. Sci., 35, 495-508.

Sikka, D. R. and S. Gadgil, 1979: On the maximum cloud zone and the ITCZ over Indian longitudes 
during the southwest monsoon. To be published in Mon. Wea. Rev.

Ulrich, T. J. and T. N. Bishop, 1975: Maximum entropy spectral analysis and autoregressive decomposition. Pure \& App. Geophys., 115, special issue, 1463-1491.

Webster, P. J. and L. C. Chou, 1980: Low-frequency transitions of a simple monsoon system. J. Atmos. Sci., 37, 368-382.

and J. L. Keller, 1974: Strong longperiod tropospheric and stratospheric rhythm in the Southern Hemisphere. Nature, 248, 212-213. 1975: Atmospheric variations: Vacillations and index cycles. J. Atmos. Sci., 32, 12831300.

Yasunari, T., 1979: Cloudiness fluctuations associated with the northern hemisphere summer monsoon. J. Met. Soc. Japan, 57, 227-242.

, 1980: A quasi-stationary appearance of 30 to 40 day period in the cloudiness fluctuations during the summer monsoon over India. J. Met. Soc. Japan, 58, 225-229.

\title{
インド周辺の夏季モンスーンにみられる約40日周期の変動の構造
}

\author{
安成 哲 三 \\ 京都大学東南アジア研究センター
}

インド周辺の夏季モンスーンには，約40日周期の大きな active-break のサイクルがほぼ毎年のように見られ ることは，気象衛星からの雲量の解析ですでに明らかにした（Yasunari，1979；1980)。今回は, 主として高層 資料を用いて，この周期性にともなら大気構造の時間的空間的变動の様相も調べた。

スペクトル解析の結果, 対流圈上層と下層を中心に, 高度場と風の場には約40日周期が卓越していることがわか った。そして, これらの変動は, 対流圈上層の高度場をのぞき, 雲量の変動に見られたように, 赤道付近からヒ マラヤへと北上する位相を示している。対流圈上層の高度場のみは, インド中部に最大振幅域をるつ standing oscillation として現われている。

クロススペクトルの手法を用いて, 温度, 湿度, 高度, 風の場に挌ける, この周期帯の鉛直構造を調べた結果, とくに温度場と高度場の構造が, 雲量の極大（又は極小）の位相の北上にともなって, 南インドから北インドへ と，大きく変質されていくことが明らかになった。たとえば，雲量の極大域にともなって，赤道インド洋上から 南インドにかけては, 対流圈上層に cold core, 最下層に warm core が存在していたのが, モンスーントラフ 域の中・北部インドへと北上するにつれ，対流圈の中・上層に Warm core が拡がり，下層に cold core の存 在する構造へと変質していく。高度場においても，対流圈を通して，ほぼ鉛直に立っていたトラフが，北上にと もなって, 次第に南へ tilt していき, 北インドでは, 下層のトラフと上層のリッジが coupling した構造へと变 質していく。この雲域北上にともなう鉛直構造の変化には, 北へいくにしたがって対流活動がより活発になるこ と, および雲量 (降水量) をもたらすじょう乱が, 南インドと中・北部インドで異なった構造であること,など が深く関連していると推測される。

この周期の active-break サイクルを支配する機構には，赤道方面への大規模な寒気の吹き出しをともなら， 南半球中・高緯度の偏西風波動が重要な役割を果していることも, 気象衛星資料, 高層天気図の解析から示唆さ れた。

以上の解析結果をもとに，約 40 日周期のモンスーンの変動は，南半球中緯度からヒマラヤにいたる子午面上 で, 複数の anomaly cell 構造をもつハドレー循環系の南北方向の变位, として把握できることを提示した。 